\title{
The value and principle of economic law in modern society
}

\author{
Ni Xue $e^{1, a}$ \\ ${ }^{1}$ Hainan Vocational College of Political Science and Law, Hainan, Haikou, 571100
}

Key words: Modern Society; Economic Law; Value; Principle

\begin{abstract}
: from the national point of view, the degree of economic development is related to the country's comprehensive national strength, China has entered the legal social track, economic operation needs the support of law. Economic law, as a product of economic development under the legal environment, has become the focus of academic circles. This paper aims to explore the value and principles of economic law in modern society.
\end{abstract}

\section{Introduction}

China is now entering a legal society, and the market economy should comply with the relevant laws and regulations. Economic law is an important part of the Chinese constitution, which covers two aspects, namely, the government's macro-control and market economy norms. Economic law as a method, not only the management scope is broader, and in commercial application value and the need to follow the principles are different. In different periods, the value and application of economic law will be different.

\section{The value of economic law in modern society}

In order to maintain the stable development of the society, the legal system plays an important role, which not only plays an important role in restraining the citizens, but also protects the rights and interests of citizens. "Economic law", which came into being with the development of national economy, is the basic guideline for the national economic operation. The main purpose of the operation of economic law is to guarantee the economic interests of citizens, all of the work revolves around the purpose of "people-oriented". In China's legal system, the value system of economic law has its particularity. Although the level of economic law has existed for a long time, but the different social and historical period, the economic operation of the management and legal binding difference. To study the value of economic law from the perspective of modern society, it is necessary to study the value of economic law from the perspective of the development of the times.

The definition of the value of economic law in modern society, due to the lack of adequate awareness, so there will be the phenomenon of blindly follow the trend of understanding. The function of economic law is to ensure the smooth implementation of economic policies. However, in the current society, there exists the phenomenon that the function of economic law is fixed on the value. This is because the value of economic law is too simple, which is enough to prove that economic law is not enough in the society.

In fact, as an important part of the constitution, economic law has the general value and special significance. Mainly reflected in the following aspects.

peration of economic law can ensure social and economic stability

The operation of economic law can ensure the stability of society and economy, and lay a good foundation for the development of the society. Due to the existence of economic law, social 
resources can be allocated fairly, which provides a guarantee for the social harmony and stability. The main reason for the existence of contradictions in the social environment is due to the uneven distribution of wealth. If the social wealth of the members of the society is lack of rationality, it will lead to disputes, which will affect social stability. The operation of economic law can regulate and standardize the economic operation of the society, and optimize the allocation of social resources, which can promote the building of a well-off society in an all-round way.

Under the environment of market economy, because part of the group to obtain high quality resources and accelerate the speed of getting rich, do not have the quality resources group needs to create rich conditions, which will inevitably get rich slowly, resulting in the gap between rich and poor. In order to narrow the income gap, it is necessary to make a reasonable distribution of social finance and government wealth, and economic law plays an important role in restraining the development of economy, which has played an important role in the development of [1]. The market economy drives the diversification of interests and the economic law plays a coordinating role. There are differences between individuals in society, and the benefits will be different. The economic law of economic operation binding can avoid monopoly industries and violence industry occupied a large market share, the market vulnerable groups played an active role in the protection of social interests, to avoid sharp.

Under the market economy environment, people will pay more attention to economic efficiency when they are engaged in economic activities. In different economic areas, the economic income and the level of benefit are different. The role of the government system is to promote the equalization of interests in various fields.

The distribution of social wealth will be restricted by the influence of the market operation mechanism. Because of the existence of economic law, the government will be given economic management function, and then adjust the wealth structure. The government should implement macro-control will accordingly preferential government, the lack of quality resources of the region to provide loans or price subsidies and so on, in order to promote the equalization of social financial allocation. Economic law will promote the realization of fair value.

China is a developing country, the national government to play a role in economic regulation. To ensure that the regulation is effective, the need for economic law constraints. The harmonious development of society also needs to ensure the fair distribution of resources through the operation of economic law. The promotion function of economic law to the harmonious and stable social environment. Under the protection of the economic law, the society runs according to certain standard to ensure the healthy and stable development of the market economy.

The rapid development of social economy, we need to build a harmonious social environment. In the face of social contradictions and the existence of controversial events, the need for economic law to play a role in the operation of the social factors of instability. It can be seen that the economic law still has the function of defending risk. Transaction platform in the society, if the operating system is not qualified, you need to play a mandatory role of law. Especially the existence of monopolistic behavior in the market economy environment, you can run the economic law to stop, in order to reduce the bad business behavior, vulnerable groups on the market in the market to protect the rights and interests of the advantages to be protected, so economic law plays a role in maintaining social harmony and stability.

\section{The principles of economic law in modern society}

The pace of China's economic development is accelerating, and economic law is more and more concerned. The principle of economic law plays a decisive role in people's legal attitude. Looking at 
the principles of economic law, including the content of the public interest protection, to protect the reasonable competition, to ensure its fairness and mandatory.

The important role of economic law is to protect the interests of the masses. China is a country under the rule of law, focusing on the interests of the people. The use of economic law to intervene in the operation of the economy, can play a role in protecting the interests of the masses, so that the masses to obtain higher benefits, but also provide benefits protection. Economic law has thus played a service function, the new order of market economy and economic efficiency can be fully upgraded [2]. In the daily production and operation, if there is no economic law, standardized operation, has not given the appropriate intervention in the market, all kinds of violations can be generated in the current open and diversified market environment, adversely affect the interests of the people. However, it is not enough to rely solely on the economic law in the operation of social economy, which requires the government to introduce relevant policies to protect the interests of the masses, and promote the development of social economy.

In the rapid development of economy, there will inevitably be some problems, resulting in the economic system there will be loopholes in the operation. To play the role of economic law to reduce the probability of crisis triggered by the vulnerability, the market structure is therefore adjusted to ensure fair and orderly competition in the market, and reasonable start. Competition is an important driving force in the market economy. If the lack of competition in the market, it will inevitably lead to the slow operation of the market, and even the phenomenon of retrogression. The existence of industry monopoly, it will have an inhibitory effect on market competition, therefore, the use of economic law to break the monopoly situation, to play the role of market regulation.

Economic law is an important part of law, so it is mandatory. Everyone is equal before the law, so the law is fair. In order to improve the credibility of the economic law, it is necessary to take some measures to purify the market. In a society full of trust, people can live in peace and work together to overcome the obstacles encountered in economic development. The fairness of economic law is mainly embodied in the maintenance of social stability, that is, to ensure the rational distribution of social wealth, but not the average distribution. There is a positive relationship between the distribution and payment of wealth. In order to improve the effectiveness of competition in the market economy, China should regulate the public and the overall situation of the social relations, so as to better prevent the bad competition in the market.

\section{Concluding remarks}

To sum up, China economy in recent years, the rapid and stable development, people gradually increase the legal concept, more and more people begin to pay attention to the economic law, and relevant content of economic law through social practice to deepen understanding. Through the interpretation of values and principles of the economic law in the modern society, can clear the environment of market economy Chinese in economic law to safeguard and restraint, maintaining stable operation of the market, restrict the adverse economic behavior, to ensure the healthy operation of the market.

\section{References}

[1] Li Yuhao. The ideas of economic law and the value of the study and interpretation of [J].business reading, 2015 (08): 32 - 32

[2] Du Hongmei. The advantages and the role of economic law in modern society to explore [J].size management, 2016 (09): 269 - 269 